\title{
Mycorrhizal Status of Bokasso (Abbo) Protected Forest and Adjacent Land uses in Wensho District of Sidama Zone, Southern Ethiopia
}

\author{
Beyene Dobo* \\ School of Natural and Computational Sciences, Department of Biology, Hawassa University; P. O. Box: 05; \\ Hawassa, Ethiopia \\ *Corresponding Author: Beyene Dobo, School of Natural and Computational Sciences, Department of \\ Biology, Hawassa University; P. O. Box: 05; Hawassa, Ethiopia
}

\begin{abstract}
Mycorrhizal status of protected forest, agroforestry practices, and mono-cropping lands were investigated in Wensho district of Sidama Zone in Ethiopia. Rhizosphere soils and root samples were analyzed for soil physicochemical properties, spore density, \& AM-root colonization following standard methods. Except some non-mycorrhizal groups, all plants surveyed in the three land-use types showed arbuscular mycorrhizal colonization, indicating a high mycorrhizal dependency of plants in this environment. A total of 26 AMF morphospecies, belonging to seven genera (Acaulospora, Entrophospora, Glomus, Claroideoglomus, Funneliformis, Scutellospora and Gigaspora), were found in the rhizospheres of selected plants in the three land uses. Spores of three genera Glomus, Funelliformis and Acauolospora had higher spore production, accounting for $58.10 \%, 17.70 \%$ and $9.29 \%$ of the total number of spores respectively. Oneway analysis of variance (ANOVA) showed that spore density and root colonization of different AM structures varied greatly among plant species both within and between different land-use types. Spore density was higher in culturally protected forest and AM colonization was higher in the agroforest. The lowest number of spores and the lowest percentage of root colonization were recorded in cropland. When land use types were considered separately or together no significant correlation between spore densities and AM colonization was observed. Cluster analysis based on the similarity in AM status with respect to spore density showed no similarity except for particular species in different land uses. Research result indicates that mono-cropping reduces spore density and AM colonization in comparison with the culturally protected forest and agroforest.
\end{abstract}

Keywords: Agroforest, arbuscular mycorrhizal fungi, colonization, crop land, spore density

\section{INTRODUCTION}

Conversion of forests to agricultural lands is one of the leading causes of loss of biodiversity in Ethiopia [1]. These land use changes have a long term impact on agricultural productivity due to erosion and soil degradation. The clearing of vegetation from an agroecosystem also affect the diversity and population density of the underground life that include bacteria, algae, fungi, nematodes, and small invertebrates. According to [2] these organisms influence ecosystem processes in nature and determine plant diversity in natural communities.

One of the important microorganisms in the soil are arbuscular mycorrhizal fungi (AMF) that form symbiotic association with roots of more than $80 \%$ of the existing terrestrial plants [3]. This plantfungal relationship is considered to be mutualistic, in which the fungus derives carbon from the host, and in return the plant gains several potential benefits from this association [4]. Different works showed that, AMF absorbs nitrogen $(\mathrm{N})$, phosphorus $(\mathrm{P})$, potassium $(\mathrm{K})$, calcium $(\mathrm{Ca})$, sulfur $(\mathrm{S})$, copper $(\mathrm{Cu})$, and zinc $(\mathrm{Zn})$ from the soil and translocate them to associated plants[5]. They also improve water relations [6], soil structure [7], reduce root pathogenic infections and promote plant growth and adaptation to biotic and abiotic factors [8].

In Ethiopia several parts of the country used to be covered with forest, declined considerably from approximately $40 \%$ to just less than 3\% during the last 100 years [9]. Many of them were changed to different agricultural systems to feed the ever-increasing populations. However, there are a few natural and protected forests and forest relics. One of these forests is a long-standing culturally protected semi-natural forest named Abbo (Bokasso) forest. 
Bokasso area is covered by vegetation, ranging from thick forest of Abbo hills to sparsely vegetate lower slopes. Increasing population pressure, deforestation for agriculture and settlement, fuel, overgrazing, and cutting trees for pulp and construction have intensively disturbed almost all of these ecosystems in recent years. Over the past years part of it has undergone changes in land use, and lower slopes of the forest has been changed into agroforestry systems with mostly leguminous trees intercropped with annuals and perennial crops and low input mono-cropping plots with mostly practiced trees, crops and different types of pulses.

It is established that changing traditional intact forests or vegetation cover into different production systems (agroforestry, cropping systems) lead to loss of plant diversity due to the reduction of understory microbial diversity, mainly AMF which are associated with survival of individual and plant communities [10]. According to [5], the composition and dynamics of populations of AMF have a marked effect on the structure and diversity of the associated plant communities, both in natural and agricultural ecosystems. The sustainability of mycorrhizae in soil is thus, important to maintain and promote productivity of croplands, rangelands and forests, and may be critical to maintenance of biodiversity [11].

In areas that are devoid of vegetation intense rainfalls on undulating landscapes during wet seasons accelerate soil erosion and land degradation. Large efforts are required to restore such degraded ecosystems.

On the basis of these facts, though restoration strategies are great challenges to human population, the role of biological alternatives is of key importance. Among these alternatives arbuscular mycorrhizal fungi (AMF) management is particularly important because it strongly influences the plant nutrition processes and the soil stabilization. However, intensive land use changes are severely affecting biological diversity and density of AMF and other essential microorganisms, and to date, little is known about mycorrhizal status in these land uses of Sidama zone of Ethiopia. The specific objectives of this study, therefore, is to assess the current status of AMF colonization, spore density, and species composition in a culturally protected natural forest, agroforestry practice, and crop land ecosystems adjacent to the culturally protected forest in Abo (Bokasso) area of Sidama Zone in Ethiopia.

These calls for urgent conservation interventions aimed at promoting farming practices which sustain biological diversity besides sustainable food production. Land use practices that are compatible with biodiversity conservation and livelihood are in return calling for studies on different aspects of biodiversity including changes in soil microbial populations.

\section{Materials AND MethodS}

\subsection{Study Site}

The study was conducted in Wensho Woreda (Districts) of Sidama Zone in Southern Ethiopia (Figure 1). The study site lies between $06^{\circ} 09^{\prime} 602^{\prime \prime}$ and $06^{\circ} 44^{\prime} 961^{\prime \prime}$ North latitude and $038^{\circ} 29^{\prime} 135^{\prime \prime}$ and 038 $30^{\prime} 985^{\prime}$ "East longitudes and within altitudes ranging from 1860 to 2080 masl. The annual mean temperature is $15-20^{\circ} \mathrm{Cof}$ which most of the mean annual precipitation of $1000-1800 \mathrm{~mm}$ falls during long rainy seasons from early May to late September. The three land-use types with their vegetation are shown on table 1 . They included: i) culturally protected forest, partly allowed for cattle grazing, but removal of any plant material is prohibited and composed of indigenous tree, bushes $\&$ shrubs ii) agroforestry system which is characterized by mixed cropping system where there is a combination of trees, shrubs, and perennial crops and iii) crop land which is characterized by the combination of perennial crops such as coffee and enset intercropped with annual crops (vegetables, cereals, pulses).All the three land-use types were located adjacently at about less than $5 \mathrm{Km}$ apart for all experimental sites. 


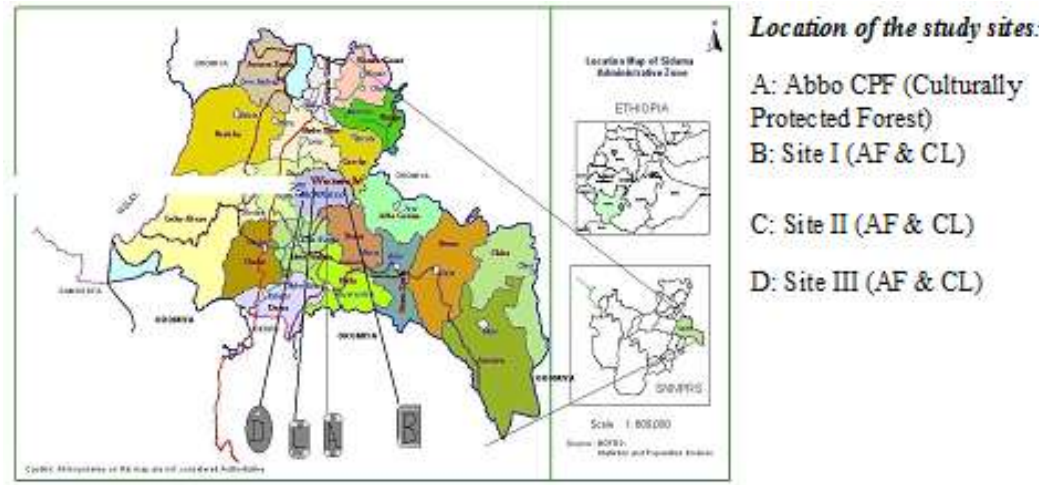

Figure1. Map of the study area

Table1. The different woody and crop plants grown in the different land use systems

\begin{tabular}{|c|c|c|c|c|}
\hline Forestry & \multicolumn{2}{|c|}{$\begin{array}{l}\text { Agroforestry system } \\
\end{array}$} & \multicolumn{2}{|c|}{ Mixed-cropping system } \\
\hline Woody plants & Woody plants & Crops & Woody Plant & Crops \\
\hline Cordia africana Lam. & Cordia africana Lam. & $\begin{array}{l}\text { Ensete ventricosum } \\
\text { (Welw.) Cheesman) }\end{array}$ & $\begin{array}{l}\begin{array}{l}\text { Catha edulis } \\
\text { (vahl.) } \\
\text { Forssk. }\end{array} \\
\end{array}$ & $\begin{array}{l}\text { Ensete ventricosum } \\
\text { (Welw.) Cheesman) }\end{array}$ \\
\hline $\begin{array}{l}\text { Croton macrostach yus } \\
\text { (HochstExDel.) }\end{array}$ & $\begin{array}{l}\text { Croton macrostachyus } \\
\text { (HochstExDel.) }\end{array}$ & Zea mays L. & $\begin{array}{l}\text { Coffea arabica } \\
\text { L. }\end{array}$ & Zea mays L. \\
\hline Millettia ferruginea Hochst & $\begin{array}{l}\text { Millettia ferruginea } \\
\text { Hochst }\end{array}$ & $\begin{array}{l}\text { Phaseolus vulgaris } \\
\text { L. }\end{array}$ & - & $\begin{array}{l}\text { Phaseolus vulgaris } \\
\text { L. }\end{array}$ \\
\hline Erythrina bruce Schweinf & $\begin{array}{l}\text { Erythrina } \quad \text { bruce } \\
\text { Schweinf }\end{array}$ & $\begin{array}{l}\text { Brassica integrifolia } \\
\text { (West) O. E. Schulz } \\
\text { (Shana) }\end{array}$ & - & $\begin{array}{l}\text { Brassica integrifolia } \\
\text { (West } \\
\text { O.E.Schulz(Shana) } \\
\end{array}$ \\
\hline $\begin{array}{l}\text { Prunus africana (Hook. f.) } \\
\text { Kalkm. }\end{array}$ & $\begin{array}{l}\text { Prunus africana } \\
\text { (Hook.f.) Kalkm. }\end{array}$ & $\begin{array}{l}\text { Saccharum } \\
\text { officinarum L. }\end{array}$ & - & $\begin{array}{l}\text { Saccharum } \\
\text { officinarum L. }\end{array}$ \\
\hline Hagenia abyssinica & $\begin{array}{l}\text { Catha edulis (vahl.) } \\
\text { Forssk.exEndl }\end{array}$ & $\begin{array}{l}\text { Ipomea batatas (L.) } \\
\text { Lam. }\end{array}$ & - & $\begin{array}{l}\text { Ipomea batatas (L.) } \\
\text { Lam. }\end{array}$ \\
\hline Juniperus procera L. & Coffea arabica L. & & & \\
\hline $\begin{array}{l}\text { Podocarpus falcatus } \\
\text { (Thunb.) R. Br. ex Mirb. }\end{array}$ & Cordia africana Lam. & & & \\
\hline Oleacapensis L. & $\begin{array}{l}\text { Croton macrostachyus } \\
\text { (HochstExDel.) }\end{array}$ & & & \\
\hline $\begin{array}{l}\text { Pouteria adolfi-friedericii } \\
\text { (Engl.) }\end{array}$ & $\begin{array}{l}\text { Millettia } \\
\text { ferrugineaHochst }\end{array}$ & & & \\
\hline
\end{tabular}

\subsection{Soil Sampling and Analysis}

In November and December, 2012, plant roots and rhizosphere soil samples were collected from the sampling sites. Sample plots with dimensions of $10 \times 10 \mathrm{~m}\left(100 \mathrm{~m}^{2}\right)$ transects with an " $X$ " design were randomly selected to collect soil samples from the rhizosphere. Triplicate samples from 0 to $15 \mathrm{~cm}$ depth were taken from the selected plants for soil physicochemical properties, mycorrhizal spore density and taxonomic analysis. Three samples for each plant species were also randomly selected from each land-use type, and $0.5 \mathrm{mg}$ of fine root samples from each plant were cut into $1 \mathrm{~cm}$ pieces, washed with tap water, preserved in $50 \%$ ethanol, and stored at $4{ }^{\circ} \mathrm{C}$ for the study of mycorrhization. Soil samples were also collected from the field in a depth of $0-15 \mathrm{cmfrom}$ the four corners and center of each sample plot and were composited in triplicates, air dried and collected in $1 \mathrm{~kg}$ of sterilized plastic bags. A total of nine soil samples ( 3 land use $\times 3$ replicates of sample plots $\times 1$ soil depth) were collected, crushed, homogenized and passed through a $2 \mathrm{~mm}$ sieve before laboratory analysis for soil analysis. Soil analysis was undertaken at the SNNPR Soil Laboratory and Debrezeite Agricultural Research Center following standard procedures and methods as described below.

Bulk density $\left(\mathrm{g} / \mathrm{cm}^{3}\right)$ was determined by core method, according to [12]. Soil textural fractions were analyzed following the hydrometric method of [13]. Soil $\mathrm{pH}$ was determined by potentiometric methods using 1:2.5soil: water ratio. Soil organic carbon (SOC) was determined by the WalkleyBlack oxidation method [14]. Total nitrogen $(\mathrm{TN})$ was determined using the Kjeldahl distillation method [15], and available phosphorous (AP) was determined using Olsen's extraction method (UV/visible Spectrometer, Lambda EZ 201) [16]. Available potassium (Av. K) was determined by 
Sodium Acetate method [17]; the exchangeable bases $\left(\mathrm{Ca}^{2+}, \mathrm{Mg}^{2+}, \mathrm{K}^{+}\right.$and $\left.\mathrm{Na}^{+}\right)$were measured by atomic absorption spectrophotometer (NOV AA 400) after extraction with ammonium acetate at $\mathrm{pH}^{7}$ [13]. Analysis of variance (ANOVA) and correlation analysis were carried out using the SPSS (version 20.0) software package.

\subsection{Root Colonization}

Colonization of roots by AMF was assessed on root samples by clearing them with $10 \%(\mathrm{w} / \mathrm{v}) \mathrm{KOH}$ and stained them with $0.05 \%$ trypan blue, according to [18]. The AM fungal structures were observed under a compound-light microscope (Olympus-bx51) at 200 to 400-fold magnification. Fungal colonization was estimated using the magnified intersection method of [19], as total root length colonization $\mathbf{R L C}=\mathbf{1 0 0}[(\mathbf{G}-\mathbf{N}) / \mathbf{G}]$, the percentage of root length colonized by hyphae only, hyphal colonization $\mathbf{H C}=\mathbf{1 0 0}(\mathbf{H} / \mathbf{G})$, the percentage of root length colonized by arbuscules, arbuscular colonization $\mathbf{A C}=\mathbf{1 0 0}(\mathbf{A} / \mathbf{G})$ and the percentage of root length colonized by mycorrhizal vesicles, vesicular colonization $\mathbf{V C}=\mathbf{1 0 0}(\mathbf{V} / \mathbf{G})$. RLC, N, A, V and $\mathbf{G}$ are designated as RLC, (total root length colonization), $\mathrm{N}$ (no fungal structure), A (arbuscules), $\mathrm{V}$ (vesicles) and $\mathrm{G}$ (total intersection) respectively. All were quantified by examining 150 intersections per sample.

\subsection{Spore Density}

Spore density analysis from each sample was processed and determined according to [20]. Accordingly, $100 \mathrm{~g}$ of each soil sample was suspended into 2 liter container in 1.5 liter of water and mixed vigorously to free spores from the soil and roots. The supernatant was decanted through standard sieves $(480,106,50 \& 38 \mu \mathrm{m})$ after having been intermittently centrifuged at 2000rmp for 5minutes using Heraeus Labofuge 200. The last pellet was suspended in $60 \%$ sucrose solution and thoroughly mixed and centrifuged at 2000rpm for 1minute. After pouring the supernatant, through the smallest mesh sieve, the spores were rinsed carefully with tap water and transfer red into plastic petridishes.

All healthy AMF spores and sporocarps of each sample were counted under 4x stereomicroscope. The spore densities were expressed as the numbers of spores and sporocarps per $100 \mathrm{~g}^{-1}$ of dry soil. Representative morphospecies were mounted on slides with PVLG. Taxonomic differentiation was made based on the descriptions of the International Culture Collection of Vesicular/ Arbuscular Mycorrhizal Fungi (http://invam.caf.wvu.edu; 2005), and following descriptions by [21].

\subsection{Statistical Analysis}

Data on percentage of AMF colonization and spore densities were transformed into arcsine and $\log (x+1)$ to calculate species richness $(S)$, Shannon-Weaver diversity index, Simpson's dominance index (D), isolation frequency (IF), and Relative spore abundance (RA) according to [22]. The data were subjected to one-way analysis of variance (ANOVA). Mean separation was done by Fisher's least significant difference (LSD) at the 0.05 level of probability [23].

\section{RESUlT}

\subsection{Soil Physicochemical Properties}

The physico-chemical soil analysis of the different land use types showed that the soil samples were sandy loam, with pH 6.0 and soil samples from Agroforestry and Forest land use systems were similar in many of the parameters except bulk density. The data also showed that cropping land use system was significantly different from the other two in $\mathrm{C}: \mathrm{N}$ ratio, available phosphorus, and in several of the basic cations (Table 1).

Table1. Physical and chemical properties of the experimental soils in the three land uses

\begin{tabular}{|c|c|c|c|c|c|c|c|c|c|c|}
\hline $\begin{array}{l}\text { Land } \\
\text { use }\end{array}$ & $\begin{array}{l}\mathrm{pH} \\
\left(\mathrm{H}_{2} \mathrm{O}\right)\end{array}$ & $\begin{array}{l}\text { SOM } \\
(\%)\end{array}$ & $\begin{array}{l}\text { TN } \\
(\%)\end{array}$ & $\begin{array}{l}\mathbf{C} / \mathbf{N} \\
\text { ratio }\end{array}$ & $\begin{array}{l}\text { P(Av) } \\
\text { Olson }\end{array}$ & $\begin{array}{l}\text { Cacmol } \\
(+) / \mathrm{kg}\end{array}$ & $\begin{array}{l}\text { Mgcmol } \\
(+) / \mathbf{k g}\end{array}$ & $\begin{array}{l}\text { Av. Kcmol } \\
(+) / \mathbf{k g}\end{array}$ & $\begin{array}{l}\mathrm{Na} \quad \mathrm{cmol} \\
(+) / \mathrm{kg}\end{array}$ & $\begin{array}{l}\text { BD } \\
\left(\mathrm{g} / \mathrm{cm}^{3}\right)\end{array}$ \\
\hline CPF & $6.0 \pm 0.12$ & $\begin{array}{l}9.98 \pm 0.0 \\
4\end{array}$ & $\begin{array}{l}\mathbf{0 . 4 2} \pm 0 . \\
23\end{array}$ & $\begin{array}{l}\text { 13.65 } \pm \\
0.75\end{array}$ & $\begin{array}{l}21.0 \pm 0.5 \\
8\end{array}$ & $3.8 \pm 0.02$ & $0.3 \pm 0.02$ & $2.50 \pm 0.9$ & $0.95 \pm 0.01$ & $\begin{array}{l}0.81 \pm 0 . \\
01\end{array}$ \\
\hline $\mathbf{A F}$ & $6.1 \pm 0.11$ & $\begin{array}{l}5.78 \pm 0.0 \\
3\end{array}$ & $\begin{array}{l}0.16 \pm 0 . \\
01\end{array}$ & $\begin{array}{l}20.72 \pm \\
1.54 \\
\end{array}$ & $\begin{array}{l}18.0 \pm 0.2 \\
9\end{array}$ & $2.97 \pm 0.09$ & $0.46 \pm 0.1$ & $2.48 \pm 0.07$ & $0.95 \pm 0.01$ & $\begin{array}{l}0.98 \pm 0 . \\
02\end{array}$ \\
\hline CL & $5.9 \pm 0.08$ & $\begin{array}{l}5.01 \pm 0.1 \\
0\end{array}$ & $\begin{array}{l}0.23 \pm 0 . \\
00\end{array}$ & $\begin{array}{l}12.64 \pm \\
0.28\end{array}$ & $\begin{array}{l}15.2 \pm 0.1 \\
8\end{array}$ & $6.72 \pm 0.01$ & $2.02 \pm 0.00$ & $2.05 \pm 0.03$ & $0.36 \pm 0.03$ & $\begin{array}{l}0.99 \pm 0 . \\
01\end{array}$ \\
\hline
\end{tabular}

$C P F$, culturally protected forest; AF, agroforest; and CL, cropland 
Mycorrhizal Status of Bokasso (Abbo) Protected Forest and Adjacent Land uses in Wensho District of Sidama Zone, Southern Ethiopia

\subsection{Plant Root Colonization and Spore Density}

All plants formed AM symbiosis, with vesicles and arbuscules, except Brassica integrifolia that did not show extensive mycorrhization and with a small number of spores in the rhizosphere. The pattern of colonization of the hyphae (HC), vesicle (VC), and arbuscules (AC) showed that vesicles cover the largest (average 24-33\%) area of the roots of the plants irrespective of the land use systems compared to the HC (20\%) and AC (17-22\%) (Table2). AM-colonization of the same species from different land-use types showed variable patterns (Tables 2). Except hyphae of Cordia africana and Prunus africana of which their hyphal colonization was higher in culturally protected forest than in agroforest, for Cordia african, Croton macrostachyus, Millittia ferruginea, Erythrina bruce and Prunus african the five species that grow in both culturally protected forest and agroforestry practices, the colonization of different AM structures in agroforestry practices was higher than those in culturally protected forest. Comparison between trees and crops that grow in both agroforestry practices and in crop lands showed that the colonization of AM structures in cropland was always lower than those in agroforest except for one species, Ipomia batatas of which its hyphal colonization was higher in croplands than in agroforests. RLC and Spore densities were significantly different in between land-use types (Table 3). However, Duncan's multiple-range tests at $\mathrm{p}<0.05$ showed (Table 6) that $\mathrm{HC}$ in between $\mathrm{CPF} \& \mathrm{AF}$ and $\mathrm{AC}$ in between CPF \& CL were not significantly different. However, the data showed that plants showed significant variations in percentage distribution of fungal structures, except Phaseolus vulgaris and Saccharum officinarum species with regard to agroforestry and mixed cropping land use systems (Table 2).

Table2. Percentage colonization of the different fungal structures in the roots of the plants in the land use systems

\begin{tabular}{|c|c|c|c|c|c|c|c|}
\hline Forest land Use & \multicolumn{2}{|c|}{$\begin{array}{l}\text { Struc. } \\
\text { Coloniz. }\end{array}$} & Agroforestry land use & \multicolumn{2}{|c|}{ Struc. Coloniz. } & \multicolumn{2}{|c|}{$\begin{array}{c}\text { Crop Land } \\
\text { Struc. Coloniz. }\end{array}$} \\
\hline Plant & $\mathbf{A C}$ & $\mathbf{V C}$ & Plant & $\mathbf{A C}$ & VC & $\mathbf{A C}$ & VC \\
\hline Cordia africana Lam. & $16.8 \mathrm{~b}$ & $26.8 \mathrm{~b}$ & Cordia africana Lam. & $24.2 \mathrm{a}$ & $27.3 \mathrm{ab}$ & - & - \\
\hline $\begin{array}{l}\text { Croton macrostachyus } \\
\text { (HochstExDel.) }\end{array}$ & $17.3 \mathrm{~b}$ & $18.9 \mathrm{c}$ & $\begin{array}{l}\text { Croton macrostachyus } \\
\text { (HochstExDel.) }\end{array}$ & $20.0 \mathrm{a}$ & $24.0 \mathrm{ab}$ & - & - \\
\hline Millettia ferrugineaHochst & $18.6 \mathrm{~b}$ & $29.5 b$ & Millettia ferrugineaHochst & $23.3 \mathrm{a}$ & $33.7 \mathrm{a}$ & - & - \\
\hline Erythrina bruceSchweinf & $18.4 \mathrm{~b}$ & $26.2 b$ & Erythrina bruceSchweinf & $23.3 \mathrm{a}$ & $27.4 \mathrm{ab}$ & - & - \\
\hline $\begin{array}{l}\text { Prunus africana (Hook.f.) } \\
\text { Kalkm. }\end{array}$ & $15.2 \mathrm{c}$ & $20.5 c$ & $\begin{array}{l}\text { Prunus africana (Hook.f.) } \\
\text { Kalkm. }\end{array}$ & $16.8 \mathrm{~b}$ & $23.3 \mathrm{ab}$ & & \\
\hline Sub-mean & 17.3 & 24.4 & & 21.5 & 27.1 & - & - \\
\hline Hagenia abyssinica & $16.4 \mathrm{~b}$ & $20.5 c$ & $\begin{array}{l}\text { Catha edulis (vahl.) } \\
\text { Forssk.exEndl }\end{array}$ & $31.6 a$ & $34.2 \mathrm{a}$ & $22.0 a$ & $27.5 b$ \\
\hline Juniperus procera L. & $12.1 \mathrm{~d}$ & $41.2 \mathrm{a}$ & $\begin{array}{l}\text { Ensete ventricosum (Welw.) } \\
\text { Cheesman) }\end{array}$ & $27.6 \mathrm{ab}$ & $38.3 \mathrm{a}$ & $14.7 \mathrm{c}$ & $27.7 b$ \\
\hline $\begin{array}{l}\text { Podocarpus falcatus } \\
\text { (Thunb.) R. Br. ex Mirb. }\end{array}$ & $21.3 \mathrm{a}$ & $23.4 \mathrm{c}$ & Coffeaa rabica $L$. & $26.0 \mathrm{~b}$ & $37.3 \mathrm{a}$ & $18.0 \mathrm{~b}$ & $23.3 \mathrm{c}$ \\
\hline Olea capensis $L$. & $\begin{array}{l}20.8 \mathrm{a} \\
\mathrm{b}\end{array}$ & $37.3 \mathrm{a}$ & Zea mays $L$. & $27.4 \mathrm{ab}$ & $39.0 \mathrm{a}$ & $16.1 \mathrm{bc}$ & $36.2 \mathrm{a}$ \\
\hline $\begin{array}{l}\text { Pouteria adolfi-friedericii } \\
\text { (Engl.) }\end{array}$ & $\begin{array}{l}18.6 a \\
b\end{array}$ & $12.4 \mathrm{~d}$ & Phaseolus vulgaris L. & $21.9 \mathrm{c}$ & $30.1 b$ & $15.4 \mathrm{c}$ & $19.1 \mathrm{c}$ \\
\hline Sub-mean & 17.8 & 27.0 & $\begin{array}{l}\text { Brassica integrifolia (West) } \\
\text { O.E.Schulz(Shana) }\end{array}$ & - & - & - & - \\
\hline Total mean & 17.6 & 25.7 & Saccharum officinarum L. & $22.0 \mathrm{c}$ & $28.0 \mathrm{~b}$ & $14.9 \mathrm{c}$ & $26.6 \mathrm{bc}$ \\
\hline & & & Ipomea batatas (L.) Lam. & $24.1 \mathrm{~b}$ & $27.4 \mathrm{~b}$ & $22.0 \mathrm{ab}$ & $25.3 \mathrm{bc}$ \\
\hline & & & Sub-mean & 25.8 & 33.5 & & \\
\hline & & & Total mean & 24.0 & 30.1 & 17.6 & 26.5 \\
\hline
\end{tabular}

$A C, V C$, percentage of arbuscular \& vesicular colonization respectively. Similar letters in columns show not significant difference between groups at $\mathrm{p}<0.05$.

The total percentage mycorrhization (RLC) calculated from the summation of AC, HC, and VC showed that the different plants in the different land use systems was in the range of $51 \%$ (Croton in forest)-87\% (coffee in Agroforestry) (Table 3). In general, data showed that more mycorrhization occurred in agroforestry (mean mycorrhizal coverage of roots of 69\%) and forest land use systems (mean mycorrhizal coverage of roots of $62 \%$ ) than the drastically changed mixed cropping system 
(mean mycorrhizal coverage of roots of 57\%). However, with a few exception, annual crops in mixed cropping system showed higher mycorrhization $(>80 \%)$ than the woody and perennial plants in other land use systems.

Rhizosphere soil samples from selected trees and crops from the three land uses harbored large number of spores ranging from 998 to 4 spores per $100 \mathrm{~g} \mathrm{~g}^{-1}$ air dried soil (Table 3). Similarly, higher spore numbers were recorded in forest land use (mean spore density of 745 spores/100g soil) and Agroforestry system (mean spore density 611 spores/100gm soil) than mixed cropping (mean spore density 447 spores/100gm soil) (Table 3) indicating spore density decreases with extensive land use than the naturally managed agroecosystems.

With a few exception, the analysis of variance (ANOVA) using SPSS showed significant difference in spore abundance amongst trees in culturally protected forest (Table 3) $(\mathrm{P}=0.007)$, however, the mean spore abundance was variable having the highest Croton macrostachyus (998) and the lowest Podocarpus falcatus (512). Spore abundance in agro-forestry practices and mono-cropping systems also showed significant difference. ANOVA showed Significant difference $(\mathrm{P}<0.05)$ for Millittia ferruginea $(\mathrm{P}=0.016)$, Catha edulis $(\mathrm{P}=0.041)$, and Brassica integrifolia $(\mathrm{P}=0.003)$ and statistically significant difference in between almost all crops in mono-cropping systems (Table 3 ).

Table3. Spore density and overall mycorrhization of the plants in the different land use systems.

\begin{tabular}{|c|c|c|c|c|c|c|c|}
\hline \multicolumn{3}{|l|}{ Forest land use } & \multicolumn{3}{|c|}{ Agroforestry land use } & \multicolumn{2}{|c|}{$\begin{array}{l}\text { Mixed } \\
\text { cropping }\end{array}$} \\
\hline Plant & SD & RLC & Plant & SD & RLC & SD & RLC \\
\hline Cordia africana Lam. & $810 \mathrm{c}$ & $73 \mathrm{a}$ & Cordia africana Lam. & $798 b$ & $72 b$ & - & - \\
\hline $\begin{array}{l}\text { Croton macrostachyus } \\
\text { (HochstExDel.) }\end{array}$ & $998 \mathrm{a}$ & $51 \mathrm{c}$ & $\begin{array}{l}\text { Croton macrostachyus } \\
\text { (HochstExDel.) }\end{array}$ & $986 a$ & $59 \mathrm{c}$ & - & - \\
\hline Millettia ferrugineaHochst & $715 \mathrm{e}$ & $72 \mathrm{a}$ & Millettia ferrugineaHochst & $588 \mathrm{~d}$ & $84 a$ & - & - \\
\hline Erythrina bruceSchweinf & $901 \mathrm{~b}$ & $66 b$ & Erythrina bruceSchweinf & $671 \mathrm{c}$ & $75 b$ & - & - \\
\hline $\begin{array}{l}\text { Prunus africana (Hook.f.) } \\
\text { Kalkm. }\end{array}$ & $659 f$ & $52 \mathrm{c}$ & $\begin{array}{l}\text { Prunus africana (Hook.f.) } \\
\text { Kalkm. }\end{array}$ & $580 \mathrm{~d}$ & $55 \mathrm{c}$ & - & - \\
\hline Mean & 816 & 63 & & 725 & 69 & - & - \\
\hline Hagenia abyssinica & $780 \mathrm{~d}$ & $57 \mathrm{c}$ & $\begin{array}{l}\text { Catha edulis (vahl.) Forssk. } \\
\text { exEndl }\end{array}$ & $956 a$ & $82 a$ & $640 \mathrm{a}$ & $62 b$ \\
\hline Juniperus proceraL. & $679 f$ & $52 \mathrm{c}$ & $\begin{array}{l}\text { Ensete ventricosum (Welw.) } \\
\text { Cheesman) }\end{array}$ & $528 \mathrm{~d}$ & $81 \mathrm{a}$ & $476 b$ & $52 \mathrm{c}$ \\
\hline $\begin{array}{l}\text { Podocarpus falcatus (Thunb.) } \\
\text { R. Br. ex Mirb. }\end{array}$ & $512 \mathrm{~h}$ & $69 \mathrm{ab}$ & Coffea arabica $\mathrm{L}$ & $858 b$ & $87 \mathrm{a}$ & $623 a$ & $53 \mathrm{c}$ \\
\hline Olea capensis $\mathrm{L}$. & $818 \mathrm{c}$ & $73 \mathrm{ab}$ & Zea mays L. & $595 c$ & $85 a$ & $389 \mathrm{c}$ & $62 \mathrm{c}$ \\
\hline \multirow[t]{4}{*}{$\begin{array}{l}\text { Pouteria adolfi-friedericii } \\
\text { (Engl.) }\end{array}$} & $578 \mathrm{~g}$ & $52 c$ & Phaseolus vulgaris $\mathrm{L}$. & $377 \mathrm{e}$ & $73 b$ & $267 d$ & $46 \mathrm{~d}$ \\
\hline & 673 & 61 & $\begin{array}{l}\text { Brassica integrifolia (West) } \\
\text { O.E.Schulz (Shana) }\end{array}$ & $7.6 f$ & $4 \mathrm{e}$ & - & - \\
\hline & & & Saccharum officinarum L. & $419 \mathrm{e}$ & $62 d$ & $292 d$ & $55 \mathrm{c}$ \\
\hline & & & Ipomea batatas (L.) Lam. & $580 \mathrm{c}$ & $68 \mathrm{c}$ & $440 \mathrm{~b}$ & $67 a$ \\
\hline Sub-mean & & & & 54.0 & 68 & 447 & 56.7 \\
\hline Mean & 745 & 62 & & 611 & 69 & 447 & $57 \%$ \\
\hline
\end{tabular}

$S D, R L C$; Spore density \& root colonization respectively. Similar letters in columns show not significant difference between groups at $p<0.05$

Correlation coefficient between AMF spore abundance and AMF root colonization was positive $(\mathrm{r}=0.609)$ indicating strong correlation and highly significant $(\mathrm{p}<0.05)$ difference between land uses. Land use types with lower spore abundance such as culturally protected forest and the cropland had medium to higher percentage root colonization compared to agroforestry practices with mixed trees and perennial and annual crops. Comparisons using student t-test showed significant $(\mathrm{p}<0.05)$ differences in spore abundance between culturally protected forest and agroforestry practice and between agroforestry practices and mono-cropping systems.

\subsection{AMF spore community composition}

A total of 26 AMF morphospecies, belonging to 7 genera (Acaulospora, Entrophospora, Glomus, Claroideoglomus, Funneliformis, Gigaspora and Scutellospora), were found in the rhizospheres of 
Mycorrhizal Status of Bokasso (Abbo) Protected Forest and Adjacent Land uses in Wensho District of Sidama Zone, Southern Ethiopia

the plants in the three land use systems. Spores of three genera Glomus, Funelliformis and Acauolospora had higher spore production, accounting for $58.13 \%, 17.70 \%$ and $9.29 \%$ of the total number of spores respectively (Table 4).

Table4. AM-spore community composition in the three land use systems

\begin{tabular}{|l|c|c|c|}
\hline \multicolumn{1}{|c|}{ Glomeromycotan genera } & Morphotypes & Spore density & \% Composition \\
\hline Glomus & 7 & 1176 & 58.13 \\
\hline Funneliformis & 2 & 358 & 17.70 \\
\hline Acaulospora & 7 & 188 & 9.29 \\
\hline Gigaspora & 3 & 142 & 7.02 \\
\hline Scutellospora & 4 & 86 & 4.25 \\
\hline Claroidioglomus & 2 & 69 & 3.41 \\
\hline Entherophosphora & 1 & 4 & 0.2 \\
\hline
\end{tabular}

Spores of Glomus were the first in spore production, and spores of Entrophospora, Scutellospora, and Claroidio glomus averaged less than $4.5 \%$ each. The three species; Glomus intraradices, Glomus hoi, and Funneliformis mossea are more abundant. Identification of spores was based on spore morphology and the number of morphospecies detected in the rhizosphere soil samples of the most common trees and crops in the three land use systems ranged from 21 to 26 . In the agroforestry systems were detected 24 morphospecies. The forest had the highest number of morphospecies (26), and the least morphotypes were found in mono-cropping systems (21). The Shannon diversity index showed ranges from 1.92 in croplands to 2.1 in culturally protected forest and evenness was ranged from 0.33 (the smallest) in cropland, 0.34 in the forest land use and 0.36(the largest) in agroforestry practices, and Simpson's diversity index shows the highest value for cropland (0.0059), agroforestry (0.0046) and the lowest (0.0042) for the culturally protected forest (data not shown).

Table5. Frequency of occurrence and relative abundances of AMF in rhizosphere soils of culturally protected forest, agroforest and cropland.

\begin{tabular}{|c|c|c|c|c|c|c|c|c|c|c|c|c|c|c|c|c|c|c|c|}
\hline AMF Genus/species Identified & 1 & 2 & 3 & 4 & 5 & 6 & 7 & 8 & 9 & 10 & 11 & 12 & 13 & 14 & 15 & 16 & 17 & $\%$ IF & \% RA \\
\hline $\begin{array}{l}\text { Acaulospora cavarnata } \\
\text { (Blaszk(1989)) }\end{array}$ & + & - & + & + & - & - & - & - & - & + & - & - & - & - & + & - & - & 29.41 & 1.05 \\
\hline $\begin{array}{l}\text { Acaulopsora foveata (Trappe \& } \\
\text { Jonos (1982) }\end{array}$ & - & - & + & - & + & - & - & - & + & - & - & + & - & + & - & + & - & 35.29 & 0.53 \\
\hline $\begin{array}{l}\text { Acaulospora tuberculata (Trappe } \\
\text { \& Jonos (1982) }\end{array}$ & + & - & + & - & - & - & - & - & - & + & - & - & - & - & - & - & - & 17.65 & 4.63 \\
\hline Acaulospora rusty & + & + & - & + & - & - & - & - & - & - & + & - & + & - & - & - & - & 29.41 & 0.72 \\
\hline Acaulosporasp .1 & + & - & - & - & + & - & - & - & + & - & - & - & - & + & - & - & + & 29.41 & 0.81 \\
\hline Acaulospora sp.2 & - & + & + & - & - & - & + & - & - & - & - & - & + & - & - & + & - & 29.41 & 0.86 \\
\hline Acaulosporasp.3 & + & - & + & + & + & - & - & + & - & - & + & - & - & - & - & - & - & 35.29 & 0.38 \\
\hline $\begin{array}{l}\text { Claroidioglomus etunicatum } \\
\text { (W.N.Becker \& Gerd.C.Walker \& } \\
\text { Schuessler (2010) }\end{array}$ & - & + & - & + & - & + & - & - & - & - & - & + & - & - & + & - & - & 29.41 & 1.29 \\
\hline $\begin{array}{l}\text { Claroidieoglomus claroidium } \\
\text { (N.C.Schenck \& G.S.Sm.C.Walker } \\
\text { \& Schuesseler (2010) }\end{array}$ & + & + & + & + & + & - & - & + & - & - & + & - & + & - & + & - & - & 52.94 & 2.01 \\
\hline Entherophosphora colombiana & - & - & + & - & - & - & - & - & - & - & + & - & - & - & - & - & - & 11.74 & 0.19 \\
\hline $\begin{array}{l}\text { Funneliformis mossae (T.H.Nicolson } \\
\text { \& Gerd.) C.Walker \& Schuessler } \\
2010\end{array}$ & + & + & + & + & + & + & - & - & - & - & + & - & + & - & - & + & - & 52.94 & 16.28 \\
\hline $\begin{array}{l}\text { Funneliformis geosporum } \\
\text { (T.H.Nicolson \& Gerd.) C. Walker } \\
\text { \& Schuessler } 2010\end{array}$ & - & + & - & - & - & + & - & + & - & - & - & - & + & - & - & - & - & 23.53 & 4.15 \\
\hline $\begin{array}{l}\text { Glomus hoi (S.M. Berch\& Trappe } \\
\text { (1985) }\end{array}$ & + & + & + & + & + & - & + & - & + & - & + & - & + & - & + & + & - & 64.71 & 16.23 \\
\hline $\begin{array}{l}\text { Glomus intraradices (N.C.Schenck } \\
\text { \& G.S.Sm.C.Walker \& Schuesseler } \\
(2010)\end{array}$ & + & + & + & + & + & - & + & - & - & - & + & - & + & + & - & - & + & 58.82 & 16.28 \\
\hline $\begin{array}{l}\text { Glomus constructum ((Trappe) C. } \\
\text { Walker \&Schuessler }(2010)\end{array}$ & + & - & + & - & - & + & - & - & - & - & + & + & + & + & - & + & - & 47.06 & 2.39 \\
\hline Glomus clarum (T.H.Nicolson \& & + & + & + & + & + & - & - & + & - & + & - & + & + & + & - & & - & 64.71 & 19.2 \\
\hline
\end{tabular}


Mycorrhizal Status of Bokasso (Abbo) Protected Forest and Adjacent Land uses in Wensho District of Sidama Zone, Southern Ethiopia

\begin{tabular}{|c|c|c|c|c|c|c|c|c|c|c|c|c|c|c|c|c|c|c|c|}
\hline $\begin{array}{l}\text { N.C. Schenck) C. Walker \& } \\
\text { Schuessler (2010) }\end{array}$ & & & & & & & & & & & & & & & & & & & \\
\hline $\begin{array}{l}\text { Glomus agregatum (N.C.Schenck } \\
\text { \& G.S.Sm.(1982) }\end{array}$ & - & + & + & + & - & - & - & - & - & - & + & - & - & - & + & - & - & 29.41 & 0.62 \\
\hline Glomu sp.1 & - & - & + & - & - & - & + & - & - & + & - & - & - & -- & - & - & - & 17.65 & 0.38 \\
\hline Gloms sp.2 & - & + & - & - & + & - & - & + & - & + & - & - & + & - & - & - & - & 29.41 & 1.11 \\
\hline $\begin{array}{l}\text { Gigaspora rosea (T.H.Nicolson \& } \\
\text { N.C.Schenck (1989) }\end{array}$ & + & - & + & + & + & - & - & - & - & + & - & - & + & - & + & - & - & 41.18 & 4.91 \\
\hline Gigaspra sp. 1 & - & + & - & - & - & + & - & + & - & - & - & - & - & - & + & - & + & 29.41 & 1.38 \\
\hline Gigaspora sp.2 & - & - & + & + & - & - & - & - & + & - & - & + & - & - & + & - & - & 29.41 & 0.48 \\
\hline Scutelospora sp.1 & + & + & & + & + & + & - & - & - & - & - & + & - & - & - & - & - & 35.29 & 2.39 \\
\hline Scutelospora sp.2 & - & + & + & - & - & - & + & - & + & - & - & + & - & + & - & + & - & 41.18 & 0.91 \\
\hline Scutelospora sp.3 & + & - & - & - & - & + & - & - & - & - & + & - & - & - & + & - & - & 23.53 & 0.43 \\
\hline Scutelosporasp 4 & - & - & - & + & - & - & - & + & - & + & - & - & + & - & + & & + & 35.29 & 0.38 \\
\hline
\end{tabular}

Key: 1. Cordia africana; 2. Croton macrostachyus; 3. Millittia ferruginea; 4. Erythrina bruce; 5. Prunus africana.; 6. Hagenia abyssinica; 7. Podocarpus falcatus; 8. Juniperus procera; 9. Olea capensis; 10. Pouteria adolfi-friedericii; 11. Catha edulis; 12. Ensete ventricosum; 13. Coffea arabica; 14. Zea mays; 15. Phaseolus vulgaris; 16. Saccharum officinarum; 17. Ipomea batatas

+ Present

- Absent

The results of this investigation also indicated that the spores of Glomus, Funneliformis and Acaulosporam were dominant. When the mean values for the three land uses compared, similar to AMF colonization, spore density also varied greatly between land-use types. Mean spore density, 447for cropped land, 611 for agroforestry and 745per $100 \mathrm{~g}^{-1} \mathrm{dry}$ soil for culturally protected forest were significantly different. Also, there was difference in spore density of the same plant species in different land uses (Table3). Cordia africana Lam., Croton macrostachyus (HochstExDel.), Millettia ferruginea Hochst, Erythrina bruce Schweinf, and Prunus africana (Hook.f.) Kalkm that grow in both culturally protected forest and the agroforest showed different micorrhization levels and spore density.

Table6. $(M \pm S E M)$ for AM colonization and spore density in different land-use types

\begin{tabular}{|l|l|l|l|l|}
\hline & \multicolumn{1}{|c|}{ AC } & \multicolumn{1}{c|}{ VC } & \multicolumn{1}{c|}{ RLC } & \multicolumn{1}{c|}{ Spore density(per 100 g dry soil) } \\
\hline Forest(n=10) & $18.12 \pm 3.1^{\mathrm{a}}$ & $25.71 \pm 0.62^{\mathrm{a}}$ & $62.37 \pm 0.86^{\mathrm{a}}$ & $744.92 \pm 12.03^{\mathrm{a}}$ \\
\hline Agroforest(n=13) & $22.22 \pm 1.19^{\mathrm{b}}$ & $28.52 \pm 0.99^{\mathrm{a}}$ & $68.06 \pm 0.53^{\mathrm{b}}$ & $611.08 \pm 1.13^{\mathrm{b}}$ \\
\hline Cropland(n=8) & $17.61 \pm 0.79^{\mathrm{a}}$ & $26.41 \pm 1.50^{\mathrm{a}}$ & $56.67 \pm 0.96^{\mathrm{c}}$ & $447 \pm 7.57^{\mathrm{c}}$ \\
\hline
\end{tabular}

Means followed by the different letters $(a-c)$ in each column are significantly different within a given land-use type according to Duncan's multiple-range test at the $p<0.05$ level of probability. HC, AC, VC and RLC are percentages of root length with hyphae, arbuscules, vesicles and total colonization, respectively.

\subsection{Correlation Analysis}

Correlation analysis indicated that total AM colonization was positively correlated with VC in the three land uses, with arbscules of $\mathrm{CPF}$ and $\mathrm{HC}$ of $\mathrm{CL}$ respectively and negatively correlated with $\mathrm{HC}$ of $\mathrm{CPF}$ and $\mathrm{AF}$ and $\mathrm{AC}$ of $\mathrm{AF}$ and CL respectively (Table 7).

Table7. Pearson's correlation coefficients between total AM colonization (RLC) and different AM fungal structures

\begin{tabular}{|l|c|c|c|}
\hline \multirow{2}{*}{ Land use type } & \multicolumn{2}{|c|}{ AM colonization } & \multirow{2}{*}{ Spore density(per 100 g dry soil) } \\
\cline { 2 - 3 } & $\mathbf{A C}$ & $\mathbf{V C}$ & \\
\hline $\mathrm{CPF}(\mathrm{n}=10)$ & $+0.696^{\mathrm{ns}}$ & $+0.739^{\mathrm{ns}}$ & $+0.739^{\mathrm{ns}}$ \\
\hline $\mathrm{AF}(\mathrm{n}=13)$ & $-0.710^{\mathrm{ns}}$ & $+0.863^{*}$ & $+0.477^{\mathrm{ns}}$ \\
\hline $\mathrm{CL}(\mathrm{n}=8)$ & $-0.919^{\mathrm{ns}}$ & $+0.994^{\mathrm{ns}}$ & $+0.066^{\mathrm{ns}}$ \\
\hline
\end{tabular}

AC\& VC are percentages arbuscules, and Vesicles respectively. *significant at $p<0.05$; ns, not significantly different

There was no statistically significant relationship between $R L C$ and spore density when land-use types were either considered separately or together. Correlation between $R L C$ and $H C$ was negative $\mathrm{r}=-$ 0.914 significantly different for AF and $\mathrm{r}=-0.203$ not significantly different for CPF but it was positive for CL r=+0.882, however not significantly different. 


\subsection{Similarity of AM Spore Density in Soils of Different Trees and Crops}

A hierarchical cluster analysis based on the similarity of AM spore density of trees and crops between the three land use types showed that AM spore density status of trees and crops do not closely resemble each other. Some crops from family Brasicaceae showed almost no spore density when compared with highly micorrhizal trees and crops such as Catha edulis \& Erythrina bruce and Zea mays and Ensete ventricosum that showed close resemblance (Figure 3).

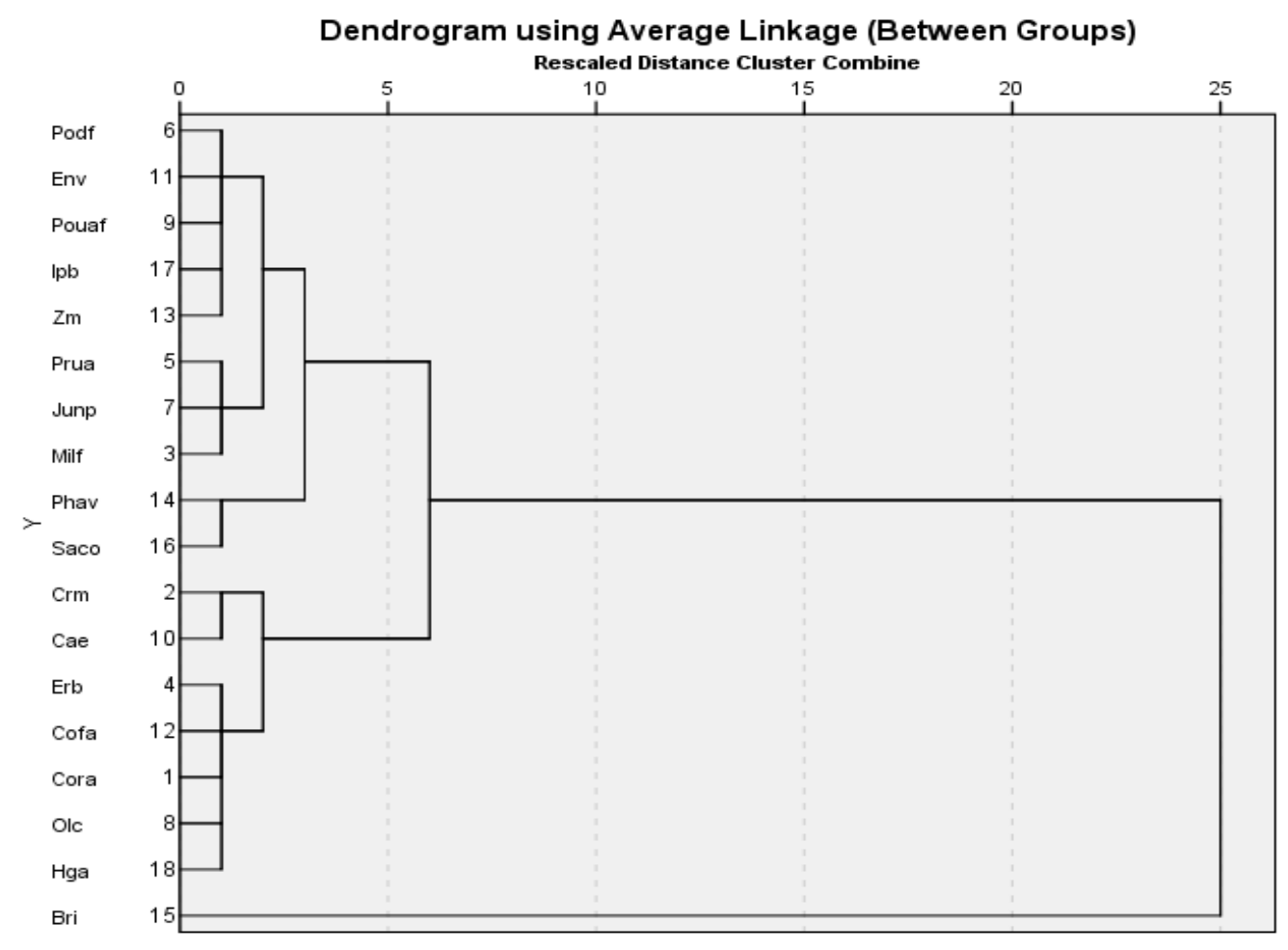

Figure3. Dendrograms of cluster analysis based on the similarity of AM spore density across the three land uses; (CPF, $\mathrm{AF}, \& \mathrm{CL})$.

1. Cordia africana; 2.Croton macrostachyus; 3.Millittia ferruginea; 4.Erythrina bruce; 5.Prunus africana.; 6.Podocarpus falcatus; 7.Juniperus procera; 8.Olea capensis; 9.Pouteria adolfi-friedericii; 10.Catha edulis; 11.Ensete ventricosum; 12.Coffea arabica; 13.Zea mays; 14.phaseolus vulgaris; 15.Brassica integrifolia; 16.Saccharum officinarum; 17.Ipomea batatas; 18. Hagenia abysinica

\section{DisCUSSION}

In this study different plant species were sampled and studied for mycorrhizal density and diversity from different land use types. Based on one-way ANOVA, the colonization of different AM structures varied greatly among plant species both within and between land-use types. AMF-colonization levels in agroforestry practices were higher compared to cropland, result supported by previous findings [24]; [25]; [26] in different parts of Ethiopia. Spore abundance was highest in land use with lower intensity (the culturally protected forest) and less abundant in more intense land uses (agroforest and cropland). Land use types such as agroforest and cropland had lower spores and high root colonization in agroforests indicate that there were a high percentage of infective vegetative propagules. Soils from agroforests had both high spore abundance (next to CPF) and high root colonization since in agroforests grows perennial trees and crops with continuous root growth.

With the exception of crop land, the rest of the land uses were dominated by perennial plants which had the highest root colonization that may be attributed to continuous root growth throughout and less disturbance through cultivation. Coffea arabica, Ensete ventricosum, Catha edulis and other perennial crops and trees in agroforests are often intercropped with food crops and receive one to two times a year slashing and manual weeding. This form of interference may explain the high root colonization and lower disruption of mycelia manifested in slightly higher AMF colonization in agroforests as compared to culturally protected forests. According to [27]; [28], hyphal network which contributes to biogeochemical cycling of nutrients ceases to function under adverse conditions or disturbance. 
In the present study the observed lower spore density and percentage root colonization in croplands is may be attributed to continuous tillage and crop shifting throughout the year in these small holder farms disrupt hyphal growth and sporulation. Therefore, the mean spore density of AMF ranging from 447 in cropland to 745 spores $\left(100 \mathrm{~g}^{-1}\right.$ dry soil) in culturally protected forest indicates the status of root colonization \& spore density were dependent on the practices of soil management in the study area. According to [29], high temperature and high light intensity could increase AMF sporulation. Our sampling was done in the dry season (November-December 2012) when the highest spore density could be expected. In the present study spore density also differed significantly among plant species both within and between land use types indicating uneven distribution of AMF spores. According to [30], AM fungal sporulation is influenced by an array of factors which come from environment, host, and fungus, and spore density tend to decrease during root growth but to increase during root inactivity or senescence. [31] Suggested that the uneven spatial distribution of AM fungal spores and the complex structure of the underground root component should be considered as major factors affecting spore density of AMF.

Mean separation showed that the spore density in culturally protected forest was significantly higher than those in agroforest and cropland, which further supported the view that disturbance reduced spore density [32]. Five of the trees (some of them leguminous) occurring in the culturally protected forest and the agroforest; Cordia africana, Croton macrostachyus, Millittia ferruginea, Erythrina bruce and Prunus africana, has a relatively high spore density. [25] Suggested that to improve success in the restoration of soil fertility including biodiversity of AMF, attention should be given to legumes, because legumes could greatly enhance the AM fungal communities and the infectivity of soil. No significant correlation between AMF colonization and spore density was observed when land-use types were either considered separately or together, which is consistent with several previous reports.

In this study, spore density and root colonization in cropland was relatively lower, than the agroforest and the culturally protected forest that was further supported by findings of [33], which suggested that AMF populations, species richness, and root colonization are often reduced by soil disturbance resulting from agricultural activities. Cluster analysis based on the similarity in spore density showed no resemblance between land uses, except for similar individual plants in the land uses. It has been well shown that among the biotic factors that could favor rapid plant re-establishment, fasten plant growth, and alleviate abiotic stress, AM symbiosis is the most effective [34].

This study provides basic information on the AMF status and indicates differences in AMF colonization and spore density of culturally protected forest, agroforestry practices and cropland at Wensho district of Sidama (Ethiopia) where agroforestry practices are dominating. This knowledge, therefore, is necessary for the reclamation and restoration of this ecosystem. Also, the results indicated that AMF colonization and spore density was reduced by continuous cropping and soil disturbance in croplands. Therefore, multipurpose agroforestry systems are effective for sustained environmental productivity, soil structure maintenance and for the restoration of AM status as compared with cropped land and culturally protected forest ecosystem in this study area.

\section{ACKNOWLEDGMENTS}

I would like to acknowledge Hawassa and Addis Ababa University and Wendo Genet College of forestry for providing me with laboratory equipment and chemicals.

\section{REFERENCES}

[1] Richter BS, Tiller RL, Stutz JC (2002) Assessment of arbuscular mycorrhizal fungal propagules and colonization from abandoned agricultural fields and semi-arid grasslands in riparian flood-plains. Appl Soil Ecol., 20: 227-238.

[2] Bever JD (2002) Host-specificity of AM fungal population growth rates can generate feedback on plant growth. Plant Soil. 244: 281 - 290.

[3] Trappe J (1987) Phylogenetic and ecologic aspects of mycotrophy in the angiosperms from an evolutionary standpoint In: Safir GR, ed. Ecophysiology of VA mycorrhizal plants. Boca Raton, Florida, USA: CRC Press, pp. 5-25.

[4] Smith SE, Read DJ (1997) Mycorrhizal symbiosis, 2nd ed. Academic Press Ltd., London, England 
[5] Tinker PB, Gilden A (1983) Mycorrhizal fungi and ion uptake, In: D.A. Robb and W.S. Pier point (eds), Metals and micronutrients, uptake and utilization by plants. Academic Press, NY. p. 21-32.

[6] Amerian MR, Stewart WS (2001) Effect of 2 species of arbuscular mycorrhizal fungi on growth assimilation and leaf water relations in maize (Zea mays). Aspects of Applied Biology.63: 1-6.

[7] Steinberg PD, Rillig MC (2003) Differential decomposition of arbuscular mycorrhiza fungal hyphae and glomalin. Soil Biology and Biochemistry.35: 191-194.

[8] Azcon-Aguilar C, Barea JM (1996) Arbuscular mycorrhizas and biological control of soil-borne plant pathogens-an overview of the mechanisms involved. Mycorrhiza, 6: 457-464.

[9] EFAP (1993) Ethiopian forestry action program: the challenge for development (Vol. I). Ministry of Natural Resources Development and Environmental Protection, Addis Ababa, Ethiopia.

[10] Van der Heijden M.G, Klironomos J.N, Ursic M, Moutoglis P, Streitwolf-Engel R, Boller T, Wiemken A, Sanders I.R. 1999.Sampling effect', a problem in biodiversity manipulation? A reply to David A. Wardle. Oikos, 87: 408-410.

[11] Allen MF, Helm DT, Trappe JM, Molina R, Rincón E (1995) Patterns and regulations of mycorrhizal plant and fungal diversity. Plant Soils, 170: 47-62.

[12] Grossman RB, Reinsch TG (2002) 5 Methods of Soil Analysis Ch2, Ed. Dane J.H, Clarke Topp G. Soil Science Society of America, Inc. Madison, Wisconsin, USA.

[13] Black C, Evans A DD, White JL, Ensminger LE, Clark FE (1965) Methods of Soil Analysis-Part 1. Physical and Mineralogical Properties Including Statistics of Measurement and Sampling, American Society of Agronomy, Madison,Wis, USA.

[14] Schnitzer M (1982) "Total carbon, organic matter and carbon," in Methods of Soil Analysis-Part 2, Agronomy Monograph, A. L. Page, R. H. Miller, and D. R. Keeney, Eds., vol. 9, pp. 539- 577, American Society of Agronomy, Madison, Wis, USA, 2ndedition.

[15] Bremner JM, Mulvaney SC (1982) "Nitrogen-Total," in Methods of Soil Analysis, A. L. Page, R.H.Miller, and D.R.Keeney, Eds.,vol. 2, pp. 595-624, American Society of Agronomy, Madison,Wis, USA.

[16] Olsen SR, Dean LA (1965) "Phosphorous," in Methods of Soil Analysis-Part 2: Chemical and Microbiological Properties, C. A. Black, Ed., vol. 9, pp. 1035-1049, American Society of Agronomy, Madison, Wis, USA.

[17] Jones B JJ (2001) Laboratory Guide for Conducting Soil Tests and Plant Analysis, CRC press, LLC.

[18] Phillips JM, Hayman DS (1970) Improved procedure for clearing roots and staining parasitic and vesicular arbuscular mycorrhizal fungi for rapid assessment of infection. Trans Br Mycol Soc., 55: 58-161

[19] Gonigle TP, Evans DG, Miller RM (1990) Effect of degree of soil disturbance on mycorrhizal colonisation and phosphorus absorption by maize in growth chamber and field experiments. New Phytologist, 116: 629-636.

[20] Brundrett M, Melville L, Peterson L (1994) Practical Methods in Mycorrhiza Research. Mycologue Publications, University of Guelph, Guelph, Ontario, Canada.

[21] Schenck NC, Pérez Y (1990) Manual for the Identification of VA Mycorrhizal Fungi. SynergisticPublications, Gainesville, Florida.

[22] Li LF, Li T, Zhao ZW (2007) Differences of arbuscular mycorrhizal fungal diversity and community between a cultivated land, an old field, and a never-cultivated field in a hot and arid ecosystem of southwest China. Mycorrhiza 17:655-665.

[23] Fisher RA, Yates F (1970) In Statistical tables for biological, agriculture and medical research. 6th ed. Davien: Hafner

[24] Zebene Asfaw (2003) Tree species diversity, Top soil conditions and Arbuscular mycorrhizal Association in the Sidama Traditional agroforestry land use, southern Ethiopia, Doctoral Thesis Department of Forest management and products, SLU. Acta Universitatis Sueciae. Silverstria, p. 263.

[25] Muleta D, Assefa F, Nemomissa S, Granhall U (2007) Composition of coffee shade tree species and density of indigenous arbuscular mycorrhizal fungi (AMF) spores in Bonga natural coffee forest, southwestern Ethiopia. For. Ecol. Manage. 241:145-154.

[26] Zerihun B, Fassil A, Mauritz V (2013) Diversity and abundance of arbuscular mycorrhizal fungi associated with acacia trees from different land use systems in Ethiopia. African Journal of Microbial Research. 7(48), pp.550

[27] Linderman RG, Pfleger FL (1994) General summary: In: Pfleger, F.L., Linderman, R.G (eds.) Mycorrhiza and plant health. APS press, St Paul Minnesota. pp. 337-344.

[28] McNaughton SJ, Oesterheld M (1990) Extramatrical mycorrhizal abundance and grass nutrition in tropical grazing ecosystems in Serengeti National Park, Tanzania. Oikos. 59: 92-96. 
[29] Cardoso IM, Boddington C, Janssen BH, Oenema O, Kuyper TW (2003) Distribution of mycorrhizal fungal spores in soils under agroforestry and monocultural coffee systems in Brazil. Agroforest. Syst. 58, 33-43.

[30] Muthukumar T, Sha LQ, Yang XD, Cao M, Tang JW, Zheng Z (2003b) Mycorrhiza of plants in different vegetation types in tropical ecosystems of Xishuangbanna, southwest China.Mycorrhiza13, 289-297.

[31] Zhao Z, Xia Y, Qin X, Li X, Cheng L, Sha T, Wang G (2001) Arbuscular Mycorrhizal status of plants and the spore density of arbuscular Mycorrhizal fungi in the tropical rain forest of Xishuangbanna, southwest China. Mycorrhiza11: 159-162.

[32] Enkhtuya B, Rydlová J, Vosátka M (2000) Effectiveness of indigenous and non-indigenous isolates of arbuscular mycorrhizal fungi in soils from degraded ecosystems and man-made habitats. Appl. Soil Ecol. 14, 201-211.

[33] Oehl F, Sieverding E, Ineichen K, Mäder P, Boller T, Wiemken A (2003) Impact of land use intensity on the species diversity of arbuscular mycorrhizal fungi in agroecosystems of central Europe. Appl. Environ. Microbiol.69, 2816-2824.

[34] Duponnois R, PlenchetteC, Thioulouse J, Cadet P (2001) the mycorrhizal soil infectivity and arbuscular mycorrhizal fungal spore communities in soils of different and aged fallows in Senegal. Appl. Soil Ecol. 17, 239-251.

Citation: Beyene Dobo, "Mycorrhizal Status of Bokasso (Abbo) Protected Forest and Adjacent Land uses in Wensho District of Sidama Zone, Southern Ethiopia", International Journal of Research Studies in Biosciences (IJRSB), vol. 6, no. 5, pp. 12-23, 2018. http://dx.doi.org/10.20431/2349-0365.0605003

Copyright: (C) 2018 Authors. This is an open-access article distributed under the terms of the Creative Commons Attribution License, which permits unrestricted use, distribution, and reproduction in any medium, provided the original author and source are credited. 